\title{
Penyerapan Merkuri Dalam Limbah Simulasi Menggunakan Zeolit Klinoptilolit
}

\author{
${ }^{1,2}$ Thamzil Las, ${ }^{1,2}$ Hendrawati, ${ }^{1}$ Amsiri \\ 1) Program Studi Kimia FST UIN Syarif Hidayatullah Jakarta \\ ${ }^{2)}$ Pusat Laboratorium Terpadu UIN Syarif Hidayatullah Jakarta
}

\begin{abstract}
Abstrak
Merkuri adalah sumber polutan yang dapat menurunkan kualitas lingkungan. Penelitian terhadap zeolit Klinoptilolit yang digunakan sebagai bahan penukar ion dan penyaring merkuri dalam limbah simulasi telah dilakukan. Penelitian ini dilakukan di Pusat Laboratorium Terpadu Bidang Analisa Lingkungan UIN Syarif Hidayatullah Jakarta. Tujuan penelitian ini adalah untuk mengetahui kemampuan zeolit Klinoptilolit dalam menyerap merkuri. Zeolit Klinoptilolit ada yang dibiarkan natural dan ada yang terlebih dahulu diperlakukan menjadi Na-zeolit dengan menggunakan $\mathrm{NaCl} 1 \mathrm{~N}$ dan Ca-zeolit menggunakan $\mathrm{CaCl} 2$ 0,02 M. Pengaruh ukuran partikel zeolit, perlakuan zeolit dan waktu kontak zeolit terhadap penyerapan diamati dengan menggunakan 3 perbedaan ukuran partikel zeolit yaitu $500 \mu \mathrm{m}->355 \mu \mathrm{m}, 355 \mu \mathrm{m}->212 \mu \mathrm{m}$ dan $\leq 212 \mu \mathrm{m}$ : 3 perbedaan perlakuan zeolit yaitu natural zeolit, Na-zeolit dan Ca-zeolit dan 6 perbedaan waktu kontak yaitu 1/2, 1, 2, 4, 6 dan 8 jam. Persen penyerapan merkuri dan nilai Kapasitas Tukar Kation (KTK) diukur dengan Spektrofotometer Serapan Atom (SSA). Pengukuran SSA menunjukkan bahwa persen penyerapan merkuri terbaik didapat pada ukuran partikel $\leq 212$ dengan zeolit yang diperlakukan dengan $\mathrm{NaCl}$ dan waktu kontak 8 jam, yaitu sebesar 87,24 \%. Nilai Kapasitas Tukar Kation (KTK) zeolit Klinoptilolit dipengaruhi oleh proses perlakuan dan ukuran partikel zeolit yaitu berkisar antara $0,32 \mathrm{meq} / \mathrm{g}$ sampai $0,81 \mathrm{meq} / \mathrm{g}$.
\end{abstract}

Kata kunci: Zeolit Klinoptilolit, Merkuri, Persen Penyerapan, Kapasitas Tukar Kation (KTK), Spektrofotometer Serapan Atom (SSA)

\begin{abstract}
Mercury is pollutant that can decrease environment quality. Research on Zeolite Clinoptilolite as ion exchange resin and filter has been carried out at Environmental Analysis Department Center for Integrated Laboratory UIN Syarif Hidayatullah Jakarta. The goal of the research was to investigate the ability of Zeolite Clinoptilolite on mercury absorption. The zeolite used on this research were natural zeolite, Na-Zeolite with $1 \mathrm{~N} \mathrm{NaCl}$, and Ca-Zeolite with $0.02 \mathrm{~N} \mathrm{CaCl} 2$. Effects of particle size, treatment, and zeolite-mercury contact duration were observed based on 3 different particle sizes that were $500 \mu \mathrm{m}->355 \mu \mathrm{m}, 355 \mu \mathrm{m}->212 \mu \mathrm{m}$ and $\leq 212 \mu \mathrm{m} ; 3$ different treatments: natural zeolite, Na-zeolite dan Ca-zeolite; and 6 different contact duration that were 1/2, 1, 2, 4, 6 dan 8 hours. Percentage of Mercury absorption and kation exchange capacity was determined by Atomic Absorption Spectrophotometer (AAS). The AAS measurement showed the best mercury absorption was reached by $\leq 212 \mu \mathrm{m}$ Na-Zeolite at 8 hours contact. The kation exchange capacity of zeolite that was range by $0.32 \mathrm{meq} / \mathrm{g}$ to $0.81 \mathrm{meq} / \mathrm{g}$ was affected by treatment process and particle size.
\end{abstract}

Keywords: Zeolite Clinoptilolite, Mercury, Absorption Percentage, Kation Exchange Capacity, Atomic Absorption Spectrophotometer (AAS)

\section{PENDAHULUAN}

Pembangunan selama tiga dasawarsa terakhir telah menyebabkan peningkatan industry yang secara nyata telah mengangkat perekonomian masyarakat. Di satu sisi dampak pengembangan industri yang kurang memperhatikan lingkungan, akan memperburuk penurunan kualitas lingkungan hidup yang akan mempengaruhi kehidupan manusia di muka bumi. Kondisi ini seiring dengan bertambahnya jumlah penduduk dunia yang tidak seimbang dengan ketersediaan sumber daya alam bagi pemenuhan kebutuhan akan 
pangan dan energi di berbagai negara termasuk di Indonesia (Witoelar, R. 2009).

Eksploitasi sumber daya alam yang tidak memperhatikan kaidah-kaidah lingkungan serta pelepasan emisi gas rumah kaca secara nyata menurunkan kualitas lingkungan hidup. Pencemaran lingkungan menjadi salah satu masalah yang memerlukan perhatian serius. Penggunaan pupuk dan obat pembasmi hama (pestisida, herbisida atau fungisida) yang berlebihan juga akan menyebabkan pencemaran lingkungan.

Salah satu limbah yang sangat berbahaya bagi lingkungan adalah limbah merkuri. Merkuri sekarang ini banyak terdapat dimana-mana di dalam ikan, air, lumpur, kosmetik, hingga Produk rumah tangga. Limbah merkuri dihasilkan dari berbagaimacam kegiatan industri, seperti dari industri peralatan-peralatan pelapisan logam (electroplating), baterai, bahan kimia, penambangan emas dan sebagainya. Demikian luasnya pemakaian merkuri, mengakibatkan semakin mudah pula organisme mengalami keracunan merkuri (Palar, H. 1994).

Pengolahan air limbah mengandung merkuri dapat dilakukan dengan proses penyerapan (sorpsi) bahan pencemar dengan menggunakan resin-organik yang berfungsi sebagai penukar ion baik berupa anion atau kation (Michael dan Pierre, 1994 dan Jianlong et al, 2000), karbon aktif (Giequel et al., 1997), dan silika gel (Leéis et al., 1996), tetapi harganya relatif mahal. Hal tersebut telah mendorong beberapa peneliti untuk mencari penyerap alternatif yang lebih murah.

Mineral zeolit merupakan mineral yang terdapat dalam batuan hasil proses pengendapan alam (Las, T. 1999) yang akhirakhir ini banyak diteliti untuk digunakan sebagai bahan penukar kation. Zeolit alam telah dikenal sejak puluhan tahun yang lalu, akan tetapi penggunaannya terbatas sebagai bahan bangunan (semen, batu ukiran dan lainlain). Pada 30 tahun terakhir penggunaan zeolit sudah meluas untuk bidang pertanian, peternakan, perikanan, industri, pengolahan air dan pengolahan limbah.

Di Indonesia zeolit pertama kali ditemukan pada tahun 1985 oleh Pusat Pengembangan Teknologi Mineral (PPTM) Bandung dalam jumlah yang besar,diantaranya tersebar di beberapa daerah di pulau Sumatera dan Jawa. Namun dari 46 lokasi penemuan zeolit, baru beberapa daerah yang ditambang secara intensif yaitu: Bayah, Cikalong, Tasikmalaya, Sukabumi dan Lampung. Jenis mineral zeolit yang sering ditemukan adalah Klinoptilotit dan Modernit (Las, T. 1998).

Zeolit adalah senyawa alumino silikat dengan struktur rangka (frameworks) dan mempunyai pori (rongga) dan saluran yang diisi oleh kation dan molekul air yang dapat mudah dipertukarkan (exchangeable) sehingga dapat mengadsorpsi ion (Sand, L. 1978).

Berdasarkan sifat tersebut penggunaan zeolit semakin luas, bukan saja sebagai penukar ion tetapi juga sebagai bahan penyerap, seperti yang telah digunakan dalam industri, misalnya pada pemurnian minyak bumi. Zeolit merupakan mineral alam yang ditemukan dalam keadaan campur dengan mineral-mineral lain, seperti kalsit, batuan lempung (clay) dan feldspar (Day, D.H. 1985).

Penelitian ini merupakan eksperimen skala laboratorium dengan menggunakan zeolit Lampung sebagai sampel. Kemampuan zeolit dalam menyerap merkuri ditentukan dengan efesiensi penyerapan dan kapasitas tukar kation (KTK). Instrumen yang digunakan untuk menganalisis sampel adalah Spektrofotometer Serapan Atom (SSA).

\section{METODE PENELITIAN}

Penelitian ini merupakan eksperimen skala laboratorium, yang dilakukan di Pusat Laboratorim Terpadu Bidang Analisa Lingkungan UIN Syarif Hidayatullah Jakarta, dimulai pada awal Desember 2008 sampai akhir Juni 2009.

Penelitian ini dilakukan untuk menguji kemampuan zeolit dalam menurunkan konsentrasi merkuri yang terdapat dalam larutan simulasi. Kemampuan zeolit tersebut diuji dengan parameter persen penyerapan dan KTK dengan melihat hubungan antara ukuran zeolit $(500 \mu \mathrm{m}$ - >355 $\mu \mathrm{m}, 355 \mu \mathrm{m}->212 \mu \mathrm{m}$ dan $\leq 212 \mu \mathrm{m}$ ), perlakuan zeolit (natural zeolit, Na-Zeolit dan Ca-zeolit) dan waktu kontak (1/2, 1, 2, 4, 6 dan 8 jam).

\section{Bahan dan Alat}

Bahan yang digunakan pada penelitian ini adalah zeolit alam dari CV Mina Tama Bandar Lampung jenis Klinoptilolit, $\mathrm{HgCl}$, 
$\mathrm{NaCl} 1 \mathrm{M}, \mathrm{CaCl} 20,02 \mathrm{M}, \mathrm{AgNO} 31 \%$, HNO3 $1 \%, \mathrm{SnCl} 2$, dan aquades.

Peralatan yang digunakan pada penelitian ini adalah gelas beaker, labu ukur, gelas ukur, erlenmeyer, botol polietilen, batang pengaduk, tisue, parafilm, alumunium foil, spatula, tang, pipet tetes, timbangan analitik, batang penumbuk, cawan, pengayak (355 $\mu \mathrm{m}$ dan $212 \mu \mathrm{m}$ ), oven, desikator, sentrifuse dan Spektrofotometer Serapan Atom (SSA) Perkin Elmer AAnalyst 700 buatan Amerika.

\section{Prosedur Kerja}

\section{Persiapan bahan}

Zeolit Klinoptilolit berbentuk butiran kasar. ditumbuk dengan menggunakan wadah penumbuk kemudian zeolit diayak dengan menggunakan saringan yang berukuran 355 $\mu \mathrm{m}$ dan $212 \mu \mathrm{m}$. Ukuran zeolit yang digunakan pada penelitian ini adalah tertahan pada saringan $355 \mu \mathrm{m}(500 \mu \mathrm{m}->355 \mu \mathrm{m})$, lolos pada saringan $355 \mu \mathrm{m}$ tertahan pada saringan $212 \mu \mathrm{m}(355 \mu \mathrm{m}->212 \mu \mathrm{m})$ dan lolos pada saringan $212 \mu \mathrm{m}(\leq 212 \mu \mathrm{m})$. Zeolit yang telah disiapkan dengan ukuran $(500 \mu \mathrm{m}->355 \mu \mathrm{m}$, $355 \mu \mathrm{m}->212 \mu \mathrm{m}$ dan $\leq 212 \mu \mathrm{m})$ diambil masing-masing sebanyak 150 gram, direfluks dengan $600 \mathrm{ml}$ aquades dalam labu destilasi (1000 ml) selama 4 jam, kemudian didekatansi. Setelah itu direfluk kembali dengan $600 \mathrm{ml}$ aquades selama 4 jam, kemudian didekantasi. Selanjutnya dikeringkan dalam oven selama 3 jam pada suhu $105^{\circ} \mathrm{C}$.

\section{Pembuatan Na Zeolit}

Tahap ini bertujuan untuk memperoleh $\mathrm{Na}$ Zeolit. Pada tahap ini zeolit kering dengan ukuran $500 \mu \mathrm{m}$ - >355 $\mu \mathrm{m}, 355 \mu \mathrm{m}->212 \mu \mathrm{m}$ dan $\leq 212 \mu \mathrm{m}$ ditimbang seberat 30 gram dan direndam dalam larutan $\mathrm{NaCl} 1 \mathrm{~N}$ sebanyak $100 \mathrm{ml}$ selama satu minggu, kemudian diganti larutan $\mathrm{NaCl} 1 \mathrm{~N}$ sebanyak $100 \mathrm{ml}$ dengan yang baru dan kembali direndam selama 1 minggu. Setelah itu zeolit didekantasi dan dicuci dengan aquades sampai bebas $\mathrm{Cl}$ (Untuk mengetahui bebas $\mathrm{Cl}$ zeolit di tes dengan AgNO3 1\%). Selanjutnya zeolit dikeringkan dalam oven pada suhu $105^{\circ} \mathrm{C}$ selama 24 jam dan disimpan dalam desikator. Zeolit dalam bentuk Na-zeolit siap digunakan untuk percobaan.

\section{Pembuatan Ca Zeolit}

Tahap ini bertujuan untuk memperoleh Ca Zeolit. Pada tahap ini zeolit kering dengan ukuran $500 \mu \mathrm{m}$ - >355 $\mu \mathrm{m}, 355 \mu \mathrm{m}$ - > $212 \mu \mathrm{m}$ dan $\leq 212 \mu \mathrm{m}$ ditimbang seberat 30 gram dan direndam dalam larutan $\mathrm{CaCl} 2$ 0,2 $\mathrm{M}$ sebanyak

$100 \mathrm{ml}$ selama satu minggu, kemudian diganti larutan $\mathrm{CaCl}_{2}$ 0,2 M sebanyak $100 \mathrm{ml}$ dengan yang baru dan kembali direndam selama 1 minggu. Setelah itu zeolit di dekantasi dan dicuci dengan aquades sampai bebas $\mathrm{Cl}$ (Untuk mengetahui bebas $\mathrm{Cl}$ zeolit di tes dengan AgNO3 1\%). Selanjutnya zeolit dikeringkan dalam oven pada suhu $105{ }^{\circ} \mathrm{C}$ selama 24 jam dan disimpan dalam desikator. Zeolit dalam bentuk Ca-zeolit siap digunakan untuk percobaan.

\section{Pembuatan Limbah Simulasi Larutan Merkuri $10 \mathrm{mg} / \mathrm{l}$}

Limbah simulasi merkuri dibuat dengan melarutkan $\mathrm{HgCl} 2$ sebanyak 1,3534 gram kedalam aquades sebanyak 1 liter. Dari perlakuan tersebut didapat larutan dengan konsentrasi $1000 \mathrm{mg} / \mathrm{l}$. Untuk mendapatkan larutan merkuri dengan konsentrasi $10 \mathrm{ppm}$ adalah dengan mengambil sebanyak $10 \mathrm{ml}$ larutan merkuri dengan konsentrasi 1000 mg/l kemudian dilarutkan dengan aquades sebanyak 1 liter. Pembuatan larutan merkuri dengan konsentrasi $10 \mathrm{mg} / \mathrm{l}$ diulangi sebanyak 5 kali sehingga didapat larutan merkuri $10 \mathrm{mg} / \mathrm{l}$ sebanyak 5 liter.

\section{Pembuatan Limbah Simulasi Larutan Merkuri $500 \mathrm{mg} / \mathrm{l}$}

Limbah simulasi merkuri dibuat dengan melarutkan $\mathrm{HgCl}_{2}$ sebanyak 0,6767 gram kedalam aquades sebanyak 1 liter. Dari perlakuan tersebut didapat larutan dengan konsentrasi $500 \mathrm{mg} / \mathrm{l}$ sebanyak 1 liter.

\section{Penentuan persen penyerapan zeolit terhadap merkuri.}

Zeolit dari masing-masing ukuran (500 $\mu \mathrm{m}$ - >355 $\mu \mathrm{m}, 355 \mu \mathrm{m}$ - >212 $\mu \mathrm{m}$ dan $\leq 212$ $\mu \mathrm{m}$ ) dan jenisnya (natural zeolit, Na-zeolit dan Ca-zeolit) ditimbang seberat 0,1 gram sebanyak 6 kali. Setelah itu dimasukan ke dalam botol polietilen dan ditambahkan limbah simulasi $\mathrm{Hg} 10 \mathrm{mg} / \mathrm{l}$ sebanyak $20 \mathrm{ml}$. 
Selanjutnya zeolit dari masing-masing ukuran dan jenisnya diputar selama 0,5, 1, 2, 4, 6 dan 8 jam, setelah itu dari masing-masing botol polietilen diambil limbah simulasi sebanyak $10 \mathrm{ml}$ kemudian di sentifuse selama 10 menit dengan kecepatan putar 700 RPM. Limbah simulasi yang telah disentrifuse diambil sebanyak $5 \mathrm{ml}$ kemudian dianalisa menggunakan SSA.

\section{Penentuan KTK (Kapasitas Tukar kation) zeolit.}

Natural zeolit dari masing-masing ukuran $(500 \mu \mathrm{m}->355 \mu \mathrm{m}, 355 \mu \mathrm{m}->212$ $\mu \mathrm{m}$ dan $\leq 212 \mu \mathrm{m}$ ) ditimbang sebanyak 0,1 gram sebanyak 2 kali. Setelah itu dimasukan kedalam botol polietilen dan ditambahkan limbah simulasi $\mathrm{Hg}$ sebanyak $20 \mathrm{ml}$. Zeolit yang sedang terkontak dengan limbah simulasi Hg 500 mg/l diputar selama 4 hari, setelah itu dari masing-masing botol polietilen diambil limbah simulasi sebanyak $10 \mathrm{ml}$ kemudian di sentrifuse selama 10 menit dengan kecepatan putar 700 RPM. Limbah simulasi yang telah disentrifuse diambil sebanyak $5 \mathrm{ml}$ kemudian dianalisa menggunakan SSA.

\section{Pengukuran Sampel}

Pengukuran merkuri dengan Spektrofotometer Serapan Atom sesuai dengan metode SNI 06-2462-1991, merkuri (Hg). Senyawa merkuri dalam sampel uji dioksidasi menjadi ion merkuri $(\mathrm{Hg} 2+)$ oleh $\mathrm{KMnO} 4$ dalam suasana asam.

\section{HASIL DAN PEMBAHASAN}

\section{Penyerapan Merkuri Oleh Zeolit I (500 $\mu \mathrm{m}$ - >355 $\mu \mathrm{m}$ )}

Dari penelitian yang dilakukan didapatkan hasil sebagai berikut:

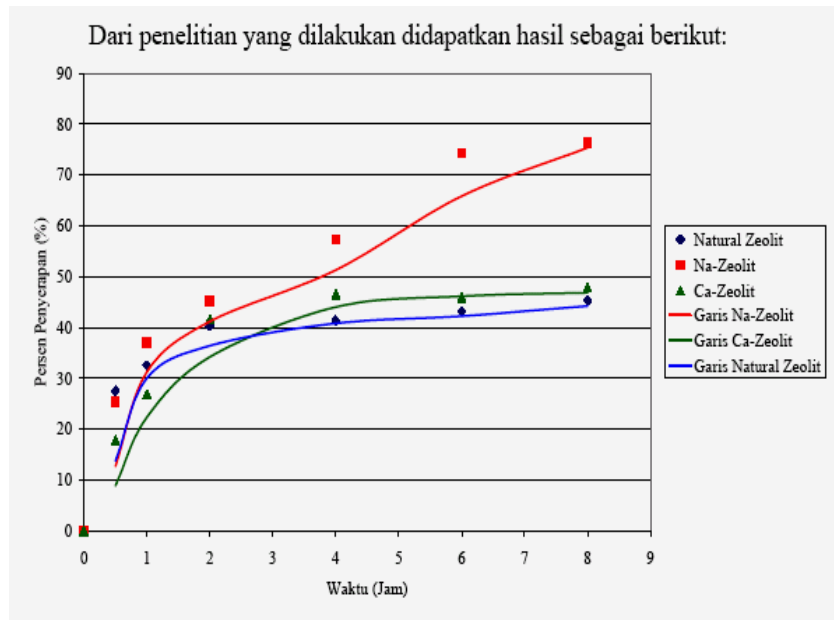

Gambar 7. Penyerapan Merkuri oleh Zeolit I (500 $\mu \mathrm{m}->355 \mu \mathrm{m})$

Dari Gambar 7 dapat ketahui bahwa, penyerapan merkuri cenderung bertambah besar seiring dengan bertambahnya waktu, hal itu terlihat untuk semua masing-masing jenis zeolit. Untuk penyerapan merkuri yang dilakukan oleh Na-zeolit cenderung lebih besar dibandingkan dengan jenis zeolit lainnya seperti natural zeolit dan Ca-zeolit. Penyerapan merkuri yang dilakukan oleh $\mathrm{Na}$ zeolit dari waktu kontak 0jam sampai 8 jam terus naik hal itu berarti bahwa sampai waktu 8 jam Na-zeolit masih mampu untuk menyerap merkuri. Hal ini berbeda dengan natural zeolit yang terlihat mulai jenuh pada waktu kontak 2 jam.

Untuk Ca-Zeolit juga tidak mampu untuk menyaingi Na-zeolit karena Ca-zeolit terlihat mulai jenuh pada waktu kontak 4 jam. Adapun nilai Persen penyerapan yang berhasil dilakukan oleh Na-zeolit mencapai sebesar $76,39 \%$, sedangkan nilai persen penyerapan yang berhasil dilakukan oleh natural zeolit sebesar 45,33\% dan nilai persen penyerapan yang berhasil dilakukan oleh Ca-zeolit sebesar $47,89 \%$ masing-masing diperoleh pada waktu kontak 8 jam. 


\section{Penyerapan Merkuri oleh Zeolit II (355 $\mu \mathrm{m}$ - >212 $\mu \mathrm{m}$ )}

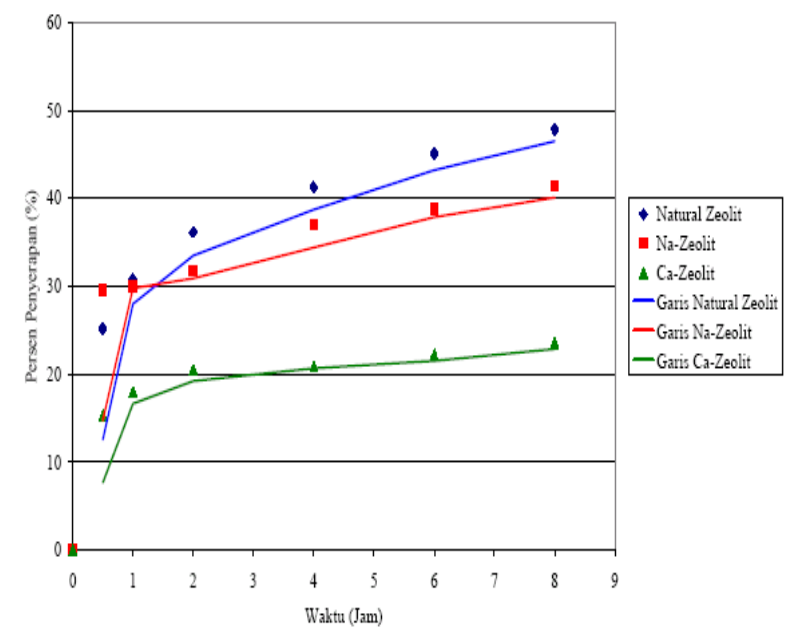

Gambar 8. Penyerapan Merkuri oleh Zeolit II (355 $\mu \mathrm{m}->212 \mu \mathrm{m})$

Dari Gambar 8 dapat ketahui bahwa, penyerapan merkuri cenderung bertambah besar seiring dengan bertambahnya waktu, hal itu terlihat untuk semua masing-masing jenis zeolit. Untuk penyerapan merkuri yang dilakukan oleh natural zeolit cenderung lebih besar dibandingkan dengan jenis zeolit lainnya seperti Na-zeolit dan Ca-zeolit.

Penyerapan merkuri yang dilakukan oleh natural zeolit dari waktu kontak 0 jam sampai 8 jam terus naik hal itu berarti bahwa sampai waktu 8 jam natural zeolit masih mampu untuk menyerap merkuri. Hal ini sama dengan yang terjadi pada Na-zeolit yang terlihat dari waktu kontak 0 jam sampai 8 jam terus naik. Dari Gambar 9 terlihat bahwa garis Na-zeolit membayangi garis natural zeolit. Untuk Ca-zeolit nilai persen penyerapannya tidak mampu untuk menyaingi natural zeolit dan Na-zeolit, hal ini terlihat Ca-zeolit mulai jenuh pada waktu kontak 2 jam.

Adapun nilai Persen penyerapan yang berhasil dilakukan oleh natural zeolit mencapai sebesar $47,86 \%$, sedangkan nilai persen penyerapan yang berhasil dilakukan oleh Na-zeolit sebesar 41,44 \% dan nilai persen penyerapan yang berhasil dilakukan oleh Ca-zeolit sebesar 23,54 \% masing-masing diperoleh pada waktu kontak 8 jam.

\section{Penyerapan Merkuri oleh Zeolit III $(\leq \mathbf{2 1 2}$ $\mu \mathrm{m})$}

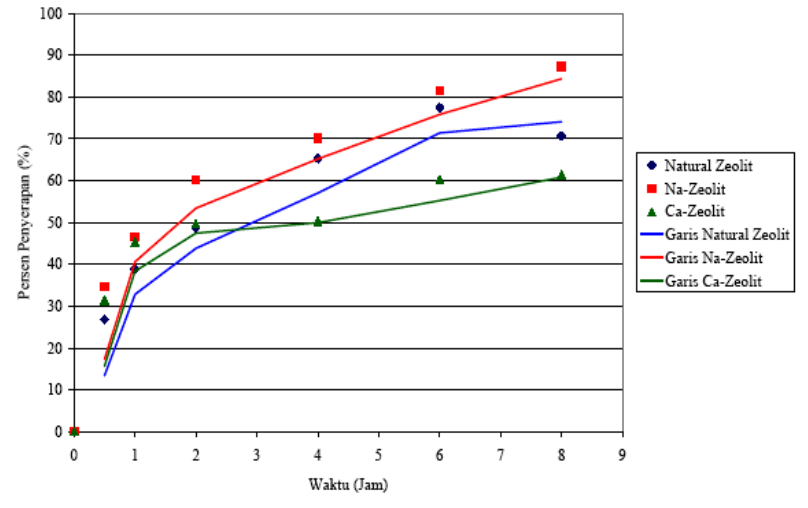

Gambar 9. Penyerapan Merkuri oleh Zeolit III $(\leq 212 \mu \mathrm{m})$

Dari Gambar 9 dapat ketahui bahwa, penyerapan merkuri cenderung bertambah besar seiring dengan bertambahnya waktu, hal itu terlihat untuk semua masing-masing jenis zeolit. Untuk penyerapan merkuri yang dilakukan oleh Na-zeolit cenderung lebih besar dibandingkan dengan jenis zeolit lainnya seperti natural zeolit dan Ca-zeolit. Penyerapan merkuri yang dilakukan oleh Nazeolit dari waktu kontak jam sampai 8 jam terus naik hal itu berarti bahwa sampai waktu 8 jam Na-zeolit masih mampu untuk menyerap merkuri. Hal ini berbeda dengan natural zeolit yang terlihat mulai jenuh pada waktu kontak 6 jam. Untuk Ca-Zeolit juga tidak mampu untuk menyaingi Na-zeolit karena Ca-zeolit terlihat mulai jenuh pada waktu kontak 2 jam.

Adapun nilai persen penyerapan yang berhasil dilakukan oleh Na-zeolit ncapai sebesar 87,24 \%, sedangkan nil i persen penyerapan yang berhasil dilakukan oleh natural zeolit sebesar 70,68 \% dan nilai persen penyerapan yang berhasil dilakukan oleh $\mathrm{Ca}-$ zeolit sebesar 61,34\% masing-masing diperoleh pada waktu kontak 8 jam.

Penyerapan terbesar merkuri adalah zeolit yang yang diperlakukan dengan $\mathrm{NaCl}$ sehingga menjadi Na-zeolit. Hal ini dapat dijelaskan bahwa zeolit yang dimodifikasi menggunakan $\mathrm{NaCl}$ untuk menjadi Na-zeolit akan mengakibatkan zeolit cenderung bersifat netral ( $\mathrm{pH}$ 6,8). Sedangkan Ca-zeolit dalam modifikasinya menggunakan $\mathrm{CaCl}_{2}$ yang cenderung asam $(\mathrm{pH} \mathrm{6,11)} \mathrm{dan} \mathrm{natural} \mathrm{zeolit}$ cenderung basa ( $\mathrm{pH}$ 7,8). Kondisi yang cenderung netral seperti yang ditunjukan oleh Na-zeolit ini yang optimal untuk penyerapan. 
Kondisi asam atau basa akan terjadi dealuminasi dalam kerangka zeolit (Suryartono, 1986). Dengan adanya dealuminasi aluminium dalam kerangka zeolit mengakibatkan jumlah aluminium dalam kerangka zeolit berkurang. Berkurangnya alumunium dalam kerangka zeolit akan berpengaruh terhadap kemampuan penyerapan. Pada struktur zeolit, semua atom Al dalam bentuk tetrahedra sehingga atom $\mathrm{Al}$ akan bermuatan negatif karena berkoordinasi dengan 4 atom oksigen dan selalu dinetralkan oleh kation alkali untuk mencapai senyawa yang stabil.

Selain itu unsur $\mathrm{Na}$ memberikan kemudahan untuk bertukar tempat dengan merkuri didalam rongga zeolit, karena didalam rongga zeolit yang kosong terisi oleh kation $\mathrm{Na}$ dengan ukuran kation yang sama. Hal ini berbeda dengan unsur $\mathrm{Ca}$ yang cenderung sulit untuk bertukar tempat dengan merkuri karena bentuk kation $\mathrm{Ca}$ berbeda-beda dan $\mathrm{Ca}$ cenderung masih mengndung air yang dapat mempersulit merkuri untuk masuk kedalam rongga zeolit.

\section{Pengaruh Ukuran Zeolit}

Dari hasil penelitian ternyata ukuran zeolit berpengaruh terhadap penyerapan. Penyerapan merkuri terbesar pada ukuran zeolit $\leq 212 \mu \mathrm{m}$. Zeolit dengan ukuran butir yang kecil ternyata memiliki kemampuan penyerapan yang besar. Hal ini dapat dijelaskan bahwa ukuran butir yang kecil menghasilkan permukaan zeolit yang terkontak dengan limbah semakin luas sehingga zeolit yang menempel dipermukaan semakin besar, hal ini yang dapat meningkatkan kemampuan zeolit untuk melakukan penyerapan.

Ukuran butir zeolit yang semakin kecil, memberikan nilai efisiensi penyerapan yang cenderung semakin besar. Hal ini dapat dipahami bahwa pada jumlah zeolit yang sama, semakin kecil ukuran butirnya akan menambah jumlah pori penyerap sehingga limbah yang terserap juga akan semakin besar atau nilai efisiensi penyerapannya akan semakin besar. (Susetyaningsih, R. 2009)

\section{Nilai Kapasitas Tukar Kation KTK}

Kemampuan pertukaran ion/ penyerapan ion atau sorpsi) zeolit merupakan parameter utama dalam menentukan kualitas zeolit yang akan digunakan, biasanya dikenal dengan Kapasitas Tukar Kation (KTK).

KTK adalah jumlah milieqivalen ion logam yang dapat diserap maksimum oleh 1 gram zeolit dalam kondisi kesetimbangan.

Tabel 1. Nilai Kapasitas Tukar Kation Zeolit I (500 $\mu \mathrm{m}->355 \mu \mathrm{m})$

\begin{tabular}{|c|c|c|}
\hline No & Sampel & KTK (meq / gram) \\
\hline 1 & I A & 0.72 \\
\hline 2 & I B & 0.81 \\
\hline 3 & I C & 0.61 \\
\hline
\end{tabular}

Dari Tabel 1 dapat diketahui bahwa nilai KTK yang tertinggi adalah pada sampel IB yaitu $0,81 \mathrm{meq} / \mathrm{g}$. Sedangkan nilai KTK yang terendah adalah pada sampel IC yaitu $0,61 \mathrm{meq} / \mathrm{g}$.

Tabel 2. Nilai Kapasitas Tukar Kation Zeolit II $(355 \mu \mathrm{m}->212 \mu \mathrm{m})$

\begin{tabular}{|c|c|c|}
\hline No & Sampel & KTK (meq / gram) \\
\hline 1 & II A & 0.51 \\
\hline 2 & II B & 0.64 \\
\hline 3 & II C & 0.42 \\
\hline
\end{tabular}

Dari Tabel 2 dapat diketahui bahwa nilai KTK yang tertinggi adalah pada sampel IIB yaitu $0,64 \mathrm{meq} / \mathrm{g}$. Sedangkan nilai KTK yang terendah adalah pada sampel IIC yaitu $0,42 \mathrm{meq} / \mathrm{g}$.

Tabel 3. Nilai Kapasitas Tukar Kation Zeolit III $(\leq 212 \mu \mathrm{m})$

\begin{tabular}{|c|c|c|}
\hline No & Sampel & KTK (meq / gram) \\
\hline 1 & III A & 0.32 \\
\hline 2 & III B & 0.46 \\
\hline 3 & III C & 0.49 \\
\hline
\end{tabular}

Dari Tabel 6 dapat diketahui bahwa nilai KTK yang tertinggi adalah pada sampel IIIC yaitu $0,49 \mathrm{meq} / \mathrm{g}$. Sedangkan nilai KTK yang terendah adalah pada sampel IIIA yaitu $0,32 \mathrm{meq} / \mathrm{g}$.

Dari data-data tersebut dapat diketahui bahwa nilai kapasitas tukar kation berbeda antara ukuran partikel zeolit $\{$ I $(500 \mu \mathrm{m}->355$ $\mu \mathrm{m})$, II $(355->212 \mu \mathrm{m})$ dan III $(\leq 212 \mu \mathrm{m})\}$ dan jenis zeolit $\{\mathrm{A}$ (natural zeolit), $\mathrm{B}$ (Nazeolit) dan C (Cazeolit)\}. Secara keseluruhan 
zeolit yang memiliki nilai KTK tertinggi adalah pada zeolit IB (ukuran $500 \mu \mathrm{m}$ - >355 $\mu \mathrm{m}$, jenis Na-zeolit) yaitu $0,81 \mathrm{meq} / \mathrm{g}$. Berarti bahwa 1 gram zeolit IB dapat menyerap 0,081 gram merkuri. Zeolit yang memiliki nilai KTK terendah adalah pada zeolit IIIA (ukuran $\leq 212$ $\mu \mathrm{m}$, jenis natural Zeolit) yaitu $0,32 \mathrm{meq} / \mathrm{g}$. Berarti bahwa 1 gram zeolit IIIA dapat menyerap 0,032 gram merkuri.

Nilai KTK tinggi yang dimiliki oleh Nazeolit kemungkinan karena penggunaan $\mathrm{NaCl}$ pada pembuatan Na-zeolit, sehingga zeolit tersebut cenderung bersifat netral, sedangkan Ca-zeolit menggunakan $\mathrm{CaCl} 2$ dalam pembuatannya yang berakibat zeolit cenderung tidak netral (cenderung asam) dan begitu juga pada natural zeolit yang cenderung tidak netral (cenderung basa).

\section{KESIMPULAN DAN SARAN}

\section{Kesimpulan}

1) Zeolit Klinoptilolit dapat menyerap merkuri yang terdapat dalam limbah simulasi.

2) Zeolit klinoptilolit yang optimal menyerap merkuri adalah zeolit yang berukuran $\leq 212 \mu \mathrm{m}$ dan yang diperlakukan dengan $\mathrm{NaCl}$ sehingga menjadi Na-zeolit dengan nilai persen penyerapan sebesar 87,24\%.

3) KTK zeolit berkisar antara $0,32 \mathrm{meq} / \mathrm{g}$ (zeolit III A) sampai 0,81 meq/g (Zeolit I B).

\section{Saran}

1) Perlu dilakukan penelitian lanjutan dengan polutan yang berbeda sehingga dapat lebih mengetahui kemampuan dari zeolit, yang nantinya dapat diaplikasikan dalam kehidupan seharihari.

2) Perlu dilakukan penelitian dengan perlakuan zeolit yang lebih beragam.

\section{UCAPAN TERIMA KASIH}

Pada kesempatan ini penulis mengucapkan terimakasih kepada Kepala Pusat laboratorium Terpadu UIN Syarif Hidayatullah Jakarta atas kesempatannya untuk melakukan penelitian ini.

\section{DAFTAR PUSTAKA}

1. Day, D. H. 1985. Atom, 11, 341.

2. Giequel, 1., D. Wolbert and A. Laplanche. 1997. Adsorption of Atrazine by Powdered Activated Carbon : Influence of Dissolved Organic and Mineral

3. Las, T. 1991. Zeolit Untuk Industri. Serpong: Lembaga ilmu Dasar-ITI.

4. Las, T. 1994. Ion Exchange and Absorpsi. Serpong: Pusat teknologi pengolahan

5. Las, T. 1994. Use of Inorganic Sorbents for Liquid Waste Treatment and Backfill

6. Las, T. 1995. Zeolite for Radioactive Waste Treatment, Techical Report, IAEARC No 7215/R2/RB, Beijing, China.

7. Las, T. dan Gunanjar. 1999. Pemanfaatan Mineral Zeolit Alam untuk Mendukung Kelestarian Lingkungan. Prossiding Seminar Teknologi Pengolahan Limbah II: BATAN.

8. Palar, H. 1994. Pencemaran dan Toksikologi Logam Berat. Rineka Cipta. Jakarta. 133-139.

9. Suryartono, Komardi, Q.S. 1986. Penerapan dan Pemanfaatan Zeolit Bayah untuk Gas dan Cairan. Pusat Penegembangan Teknologi Mineral: Bandung.

10. Susetyaningsih, Retno. Dkk. 2009. Karakterisasi Zeolit Alam pada Reduksi Kadar Khrom dalam Limbah Cair ISSN 1978=0176. Sekolah Tinggi Tenaga Nuklir BATAN. Yogyakarta

11. Witoelar, R. 2009. Bersama Selamatkan Bumi dari Perubahan iklim. Kementrian Lingkungan Hidup Republik Indonesia. Jakarta. 